\title{
Not Holding to Fixed Views
}

\author{
Ajahn Amaro ${ }^{1}$ \\ Published online: 31 January 2019 \\ (C) Amaravati Publications 2019
}

The phrase "I'm right, you're wrong" is the archetypal expression of our tendency to attach to views and opinions: "If I think it, it must be true, and if you think differently, sorry, but you're wrong. You might be a good person, but you're just wrong." This is the very opposite of the attitude expressed in the last four lines of the Mettā Sutta (SN 1.8):

By not holding to fixed views, the pure hearted one, having clarity of vision, being freed from all sense desire, is not born again into this world.

"Not holding to fixed views" means letting go, not clinging. In a number of his teachings, the Buddha talked about four different kinds of clinging, four different zones of attachment. The first kind is clinging to sense-desire, sense-pleasure ( $k \bar{a} m$ upādanna). The second kind is clinging to precepts and practices: rules, observances, conventions (sìlabbat-upādāna); the blind belief in conventional structures. This can include rules of religious behavior, but also be things like the value of money. The next kind of clinging is clinging to the feeling of self, attavād-upādāna, the "I, me, and my" feeling. But the kind of clinging examined here is clinging to views and opinions, as in the line from the Mettā Sutta: "not holding to fixed views," dițthiñca anupagamma in Pali. This final type of clinging is called diț̣h-upādāna.

In our culture, we tend to hold opinions in very high regard. The tendency to take our opinion or view as an ultimate reality is a strong habit for all of us; if I see something in a particular way, what I think is right, and so I am right! But if we attach to that way of thinking, if we take it to be absolutely valid, we will find ourselves in conflict with those who think differently:

Excerpted from I'm right, you're wrong! by Ajahn Amaro. Amaravati Publications, 2016

Ajahn Amaro

ajahn.amaro@gmail.com

1 Amaravati Buddhist Monastery, Hemel Hempstead, Hertfordshire HP1 3BZ, UK
"If you think differently from me, you must be wrong." This can lead to friction, contention, and all kinds of quarrels at the family, social or political level, even to the point of leading to warfare over a view, or a simple difference in understanding. This is an important issue in our lives and if we do not understand its core, how it works in our own minds, there's no real hope of solving it on a broader scale. So we need to explore that quality of contention, that divisiveness, that polarity. Where does it come from and what can we do about it?

One problem that may arise is that if I am right and you are wrong, I might feel it's my duty to set you straight: "I'm pure, you're impure, and it's my sacred duty to fix you so that we have purity." On a social level, this led to the terrible depredations of Nazi Germany or the Rwandan genocide, "ethnic cleansing" in the Balkans, or those "religiously" inspired militias who feel it's their duty to defend the word of their lord by wiping out those who think or act differently. Similar evils have been frequently committed in the name of democracy. This kind of attachment and clinging, of getting lost in our own viewpoint, creates very real difficulties, tensions, suffering, and harmful experiences in the lives of many people.

The more we believe in our opinions, the greater our investment in the rational mind. Indeed, the more logical our thoughts may be, the more tidy our rationale, the more perfectly valid it may seem to be to straighten somebody else out because they are "wrong." And even if we do not think of setting someone straight as a sacred duty, we can still have a strong attitude of righteousness.

It might be the case that we have been praised for that quality during our childhood and upbringing, taught that righteous indignation is a good quality. On one level, we can make a tight logical case for thinking that way, and say it's absolutely true by our own judgment and reasoning. But then, we will not recognize what it does to our own heart and the way that we relate to others. The issue is further complicated by the fact that sometimes stepping up and taking action may be exactly the appropriate thing to do, irrespective of our feelings of righteous indignation.

The basis on which we take action is the element that makes the difference, as illustrated by the following story. In the early 
days in Ajahn Chah's monastery, Ajahn Sumedho was the only Westerner living there. He was a very ardent, idealistic monk who took the monastic training extremely seriously and was very committed, as all good monastics should be. But he had grown up in an atmosphere of righteous American conditioning, and had a different way of going about things from some of the other monks in the monastery. A Thai monk who was also living there was very loud-mouthed and outspoken, incautious about his speech. This was extremely unusual in Thailand, where people tend to be much more restrained, non-confrontational or outspoken in average social interactions. The young Bhikkhu Sumedho took great offense at this monk's behavior and thought: "This is totally out of order, and why isn't Ajahn Chah saying anything? He lets this guy just carry on and make a fool of himself and upset everybody, and everyone can see he's out of order but no one is saying anything! This is ridiculous! Somebody ought to get up and... even though I'm a junior monk I really ought to... if somebody doesn't say something, I will!"

This went on for some months and he grew more and more indignant. Eventually Ajahn Chah went off to visit a branch monastery for a few days, and it happened that at the same time, there was the fortnightly recitation of the monastic rule, after which the teacher gives an instructional talk and then asks: "Is there any business that the Sangha wants to bring up?" With Ajahn Chah away, it was thus one of the senior monks leading the meeting and who said: "Has anyone got any business to discuss?" Even though Ajahn Sumedho had only been a monk for two or three years and the loud-mouthed bhikkhu was a bit senior to him, he said: "Yes. I've got something I'd like to bring up. I'm very concerned about the conduct of Bhikkhu X, and..." He had a whole list of different occasions, he had witnesses, he had the evidence, he had all his criteria; everything was lined up. And he was "right": all the things for which he criticized the monk were factually valid - you could see that other people had been upset or they took offense and walked away, and so on. While Ajahn Sumedho was saying this, the offending monk was looking at the floor and everyone else was listening, taking it all in. Finally he got to the end of his Dhammic diatribe and the senior monk said: "We'll just wait till Luang Por Chah gets back and then we'll bring this matter to his attention."

A few days later Ajahn Chah returned, and word reached him pretty quickly about this outrageous confrontation by the foreign monk. He took note of that. But before Ajahn Chah came back, the monk who'd been criticized and shamed in this way left the monastery and wasn't seen again. After a few days, Ajahn Chah found a moment to chat with Ajahn Sumedho and said: "You know, Tan Sumedho, what you said about the loud-mouth monk, you did something very harmful there. You meant well, but what you did was harmful because even though..." the expression he used in Thai was bahk bahp, daer jai di, which means: "His mouth is evil, but his heart is good." "He's got bad verbal habits. I knew that. Of course, everyone knows that.
But how many monasteries do you think the fellow had to leave before he came here? This was the one place where he could stay and practice, because I made space for him. But now you've closed the door on him and you have to take responsibility for that; he can't stay here anymore because you shamed him publicly. And so you have to acknowledge that that was poorly done on your part. You were right in fact, but wrong in Dhamma."

That to me is an extremely precise and helpful teaching. In our minds, the two ideas are often meshed together: "If I'm right, then however I act on that rightness is good"; this is the principle of the "Antinomian heresy" in Christian tradition. In terms of the Buddha's teaching as well that goodness is not guaranteed, it's not necessarily so, because there's a principle whereby it's not just a matter of what we do, but the way that we do it. It's not just the opinion we have or the way we see things, but how we express them that makes the difference. That's the crucial element, and that's what the young Ajahn Sumedho had missed. It was a very powerful lesson for him; he has remembered it ever since.

So how do we respond when someone says: "I know I'm right?"

I was at a meeting of the community some years ago where there were some differences of opinion. Twenty or so people saw things one way, but one person in the group saw it very differently - they claimed that in a certain crisis " $100 \%$ of the problems in the situation were X's fault; I was not to blame at all." At first no one else in the group could take that seriously, some knowing from direct experience that what this person said was inaccurate. So it was gently pointed out to them:

"Here we are - there are twenty of your peers saying 'We see it like this', and you're saying 'No, you're all wrong.' Does that seem reasonable? Do you really mean to say you believe you contributed $0 \%$ to the difficulties of the issue?" To which the person replied with complete conviction: "That's right. None of it was my fault." "And if all of us see it differently?" "Then you're wrong" - and said with a sweet smile.

In this case, it was very helpful to be able to see that person's absolute and non-reflective attachment to their view; the fact that they had such an irrational certainty in their own rightness demonstrated that: "We're not working with an adult mentality here; this is a person lost in a childish reaction," and so the group was able to take the issue on from there. Often, like this individual, we do not have a reflective approach. We do not see how tightly we are holding something, or have any kind of perspective on it. We need therefore to learn how to recognize that feeling of rightness and explore it, so that even if we feel we are a $100 \%$ certain, we can reflect on that feeling before we decide how to handle the situation.

There's a principle called "practicing Dhamma in accordance with the Dhamma," dhammānudhamma patipatti (S 55.5), which is one of the essential elements, the final factor for stream entry. If we really want to be free, it's absolutely essential to understand and embody this principle, to truly see the difference 
between just having a sense of rightness, and recognizing that the way we act needs to be in accordance with Dhamma, with fundamental reality. The challenge is to find how to bring about that accordance with reality. One problem is that our attention becomes caught by the issue itself. Something offends our ideals, goes against our spiritual principles, or is strongly loaded emotionally, and we become so taken by it that we do not see the emotion with which we are handling it.

I read an article a number of years ago about two sets of astronomers who were both trying to carry out the same kind of measurements to decide whether the universe was likely to keep on expanding or not, and the exact rate at which it was expanding. They had two big telescopes to help make those measurements, and they were competing over who would be first to have the final proof about this question. On one level, there were very refined and intellectual high-tech astrophysical issues, ostensibly to find out the truth about the nature of the universe; but on the emotional level, it was more like a scrap between eight-year-olds in the playground. One of the project heads commented: "Some people say that gravity is the most powerful force in the universe; I disagree, I think professional jealousy is stronger." I thought that was very astute. What the scientists really cared about was who would end up on top. But at least he had noticed that kind of dynamic was operating.

One approach to meditation is understanding how the mind becomes caught in these contentious states, where the reptile brain, the sense of conflict and contention, quarrel, competition, takes over our field of experience, and how we get into situations where we are clinging to our "rightness" but it's not making us any happier.

Once a Brahmin scholar called Danḍapani, whose name means literally "stick in hand," i.e., "the man with the walking-stick," came to the place where the Buddha was sitting, meditating (Madhupindika Sutta, M 18). He was a professional debater who'd heard of the Buddha's reputation and came to ask him: "What's your philosophy? What kind of teaching do you proclaim? What kind of views do you assert?" The Buddha, being a very quick judge of human character, said: "I proclaim such a teaching that espouses non-contention with anyone in the world." The account says that Daṇdapāni then clicked his tongue, his brow puckered into three furrows and, wagging his head from side to side with nothing to say, he went away and left the Buddha by himself.

Later the Buddha described this encounter briefly to the monks and said:

When the mind doesn't grab hold of things, when you don't find any "thing", any opinion, any fixed position to delight in, then that is what brings about the end of quarrels, the end of disputes, malicious speech, the taking up of weapons and of argument - that's where contention comes to an end, where the mind doesn't relish taking hold of 'this is my position!'
This very brief statement left the monks a bit perplexed, so they went to Ven. Mahā-Kaccāna, who was expert at explaining in detail the Buddha's brief or cryptic statements. Mahā-Kaccāna gave a wonderful description of how the qualities of contention arise.

Dependent on the eye and forms, eye-consciousness arises. The meeting of the three is sense-contact. With sense-contact as condition, there is feeling. What one feels, that one perceives...

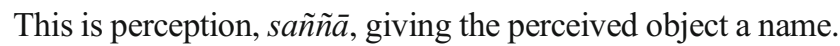

What one perceives, that one thinks about. What one thinks about, that one mentally proliferates.

So the chattering mind takes that perception and launches off with it.

With such conceptual proliferation (papañca) as the source, the heart is beset by mental perceptions and notions characterized by the prolific tendency, with respect to the past, the future and present forms cognizable through the eye.

But then, if nothing is found there to delight in, to welcome and hold to, this is the end of the underlying tendencies to lust, aversion, views, doubt, conceit, desire for being and ignorance. This is the end of resorting to weapons, quarrels, brawls, disputes, recrimination, malice and false speech. Here these harmful, unwholesome states cease without remainder."

This process begins with a sense-contact. Something impacts one of the senses; there's a contact, and then there's a feeling of attraction or aversion, or a neutral feeling. That feeling leads to perception. So we might give a sound that we hear a name, or it might cause a trigger in the mind of interest or enthusiasm, or have an emotional impact, and that recognition is sañ $\tilde{a}$; not just the sense perception but the tone that goes with it.

The words "sign" and "designation" are related to the Pali word sañ̃̄a. That naming action brings up thought, vitakka. And from thought comes papañca, the strings of conceptual proliferation. That is when the chattering mind really launches off, and that's what eventually leads to a feeling of "me oppressed by the world," "me pressured by this thing I'm stuck with that I do n't want," "me pursuing this thing that I haven't got," "me being burdened by this painful experience," or "me caught up in this particular quality." It leads to the array of perceptions and notions that besets the heart and creates a feeling of alienation, of a "me" in a state of tension with "the world."

So, states of conflict and contention develop because we take a thought or a perception, and then the mind runs with it. The guided meditation which follows this article looks more closely 
at how that process works, and how we can follow it back to the source; the simple, straightforward sight, sound, feeling, smell, taste, or thought; the innocence, the simplicity of the raw sense perception. The sañ̃̃a , the vitakka, and the papañca all develop from something straightforward: a feeling, a sound, a sight. In meditation, we can train ourselves to go back to the source of an individual perception or idea, or just a memory floating up, and then stay with the simplicity of that. In the Korean tradition, there is a beautiful collection of teachings which talks about this practice; there it's known as "tracing back the radiance" (Buswell Jr. 1991). In meditation, we'll find that ninety-nine times out of a hundred, if we follow the conflicts the mind gets into and the tensions it creates back to what triggered them, we'll have left behind that experience of tension and alienation, that conflicted state, we'll have let go of it.

\section{Guided Meditation}

Settle down and sit in a comfortable posture for meditation: cross-legged, kneeling, or on a chair, however you choose.

First of all, take a moment to notice how you feel. It always helps to briefly take stock of what the mood is. Do you feel inspired? Tired? Happy? Depressed? Whatever it might be, just take a moment to notice what that tone, the mood of this moment is.

Feel the presence of the body. How is it? Does it feel light? Heavy? Comfortable? Uncomfortable? Hot? Cool? How is it? Notice what you brought here with you. What's your starting point? By recognizing that this is the material you are working with, this body, this mind, you can let your actions, your attitude, guide the body and mind towards what will be useful, beneficial for you.

Now feel the presence of the spine. Bring attention to your backbone. Invite the body to sit upright. Let the spine lengthen, stretch to its full natural extension.

Bring the quality of alertness and attentiveness to what you are doing, helping to brighten and energize the body, the mind.

And then, around the spine as the central column, the axis of your physical world, take a few moments to let the body relax in a full and complete way. Relax the muscles of the face, neck, and shoulders.

Relax the arms and the hands.

Relax the trunk of the body. Let the chest be a little more open, the abdomen soft and relaxed, free from tension.

The hips, the legs: let them soften and loosen. Invite the whole body to be at ease, to settle at this particular time, this particular place. Give yourself permission to let go of all tension, to be alert, attending to the present moment.

To sustain or establish that attention in the present, we take a simple meditation object like the feeling of the breath. Without changing or modulating the breath in any deliberate way, let the natural rhythm of the breathing be the center of attention for the next little while, feeling each inhalation, each exhalation. Invite the mind, the attention, to rest and to settle in this present moment; the weight of the body, the breath entering and leaving - the simplicity of this moment.

When you find the attention has drifted away, let go of what the mind has latched onto; come back to the present moment, letting the breath be like a central point, a flag marking this very moment. You set the intention to follow the breath, but then you find the mind is becoming distracted. The next thing you know, you are planning next week, recollecting a conversation early this morning, a film you watched last night, your grandmother's cottage in a foreign country.

Whenever you notice that your mind has drifted off in that way, see if you can follow it back. See if you can trace the chain of thought that led up to that association.

Follow the string of thoughts and associations to see where the association came from. Did it come from a sound? A feeling in your knee? A random memory of a fragrance?

Whenever you find some kind of string of associations, of conceptual proliferation, see if you can follow it back, theme by theme, thought by thought, to see where it came from.

And once you get to the root, when you recognize: "It was just that sound! It was that feeling in my knee!" stay with that perception for a moment. Stay with that simple recognition. Feel its tone, its ordinariness. Then after a moment, let go. Go back to the breath. Re-establish attention in the present.

You can extend this practice one step further to explore the quality of conflict by deliberately bringing to mind an occasion that had a powerful impact on you, someone with whom you have argued, an ex-partner, parent, child, co-worker, co-monastic. Bring to mind some occasion of conflict, of a difference of opinion. You do not need a whole story, just the very briefest of thoughts, a word or a couple of words: "That argument." Then see, note, sense the chain of thoughts and feelings that is triggered when you deliberately launch the papañca stream. When the mind is drawn into this stream - this flood of associations so that you are lost in it — stop! Then follow it back through each link in the chain, to where it began with perhaps a single word. How unremarkable, ordinary that original word is, and yet it can give rise to such a flood, an ocean of associations, with their qualities of pressure, tension, stress. When we follow it back to that single simple word, that one idea, how does it feel? What's the tone? What's the quality at the root, before all the thoughts and associations are launched from it? Wonderfully simple, is not it?

\section{Reference}

Buswell Jr., R. E. (1991). Tracing back the radiance: Chinul's Korean way of zen. Honolulu: University of Hawaii. 